\title{
POSSIBILITIES OF OBTAINING RAIL TRANSPORT DATA FOR THE PURPOSE OF UPDATING THE SOURCE DATA OF THE ERIC MOBILE APPLICATION
}

\begin{abstract}
The flow of information is important in any area of human life. That's why people try to develop applications to support the flow of information. But then it is also important to protect information, which means that not all employees have access to all information. In practice, this means above all a competitive advantage over other companies in the same sector. The purpose of the article is to define the positive and negative aspects of trade secrets from the customer's point of view in passenger and freight rail transport. The main goal is to connect the information systems of individual infrastructure managers and carriers into the ERIC MOBILE application in compliance with the conditions of modularity.
\end{abstract}

Keywords: freight carrier, passenger carrier, infrastructure manager, ERIC Mobile, trade secret

Juraj Čamaj ${ }^{1}$

${ }^{1}$ Faculty of Operation and Economics of Transport and Communications University of Žilina, Univerzitná 8215/1, 01026 Žilina; +421/41 513 3434; juraj.camaj@fpedas.uniza.sk

Štefan Čarný ${ }^{2}$

${ }^{2}$ Faculty of Operation and Economics of Transport and Communications University of Žilina, Univerzitná 8215/1,010 26 Žilina; +421/41 513 3434; stefan.carny@fpedas.uniza.sk

Adrián Šperka ${ }^{3}$

${ }^{3}$ Faculty of Operation and Economics of Transport and Communications University of Žilina, Univerzitná 8215/1, 01026 Žilina; +421/41 513 3434; adrian.sperka@fpedas.uniza.sk

\section{Introduction}

The roots of competition in rail transport must be traced to the beginnings of liberalization. It began in the 1980 s in the United States with the goal of declining the performance of passenger and freight rail transport. In Europe, the beginning of the transformation is considered to be 1991, when the first railway package was adopted as Directive 4441/1991. Carriers in individual countries have started to progress gradually, the full opening of the market for passenger and freight rail transport took place in 2007.

The experience with the liberalization of the railway market in Romania is discussed in an article (Busu \& Busu, 2015). On several case studies, it reveals the pros and cons of the whole process.

On systemic risk and its increase in the context of the liberalization of the rail market in Europe dealing with the article (Laperrouza, 2009). The article describes the increase in risk levels in the creation of a single European railway area. He considers that most risks in this area are limited to their management and ignore the institutional dimension.

The article aims to propose data collection to the ERIC MOBILE application in a modulation environment based on analyses of the impacts on carriers and carriers in freight transport, as well as passengers in passenger transport. First of all, the main criteria need to increase the competitiveness of railway companies while reducing the negative impact on customers (impossibility of prospective connections of all carriers in passenger transport, or declining transport performance with one hundred percent own structure of the state).

\section{Language}

The European rail market is characterized by the fact that it is not just about one country or one user. It is therefore certain that the users of the ERIC MOBILE application will not be from only one country. The very specificity of transport and washed technological operations requires the greatest possible proximity to users (carriers, transporters, infrastructure manager's operational staff) and therefore the installation of the application should be able to choose the language version (as well as the database base) of the application. The basic language mutations should be the languages of the countries where the services of ERIC MOBILE products are already used. In Figure 1, universal and other language mutations are proposed.

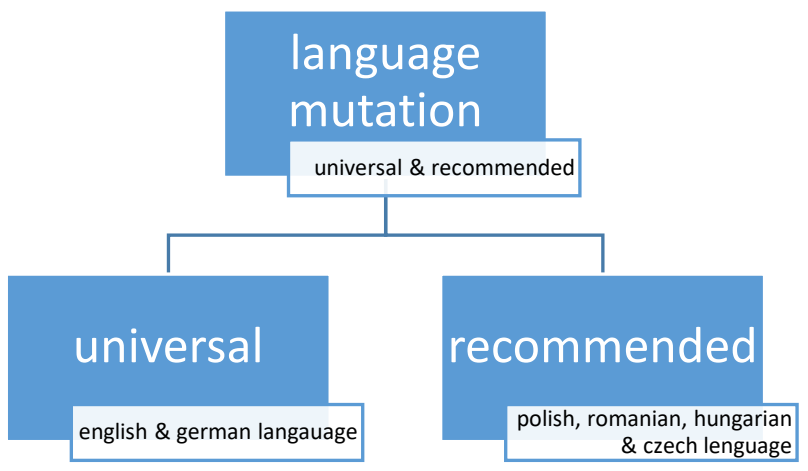

Fig. 1. Universal and recommended language versions

The users of the system will be representatives of transport, shipping and forwarding companies, which have their own data requirements for the application. Therefore, from the point of view of securing singularity, it is 
important that the application includes the possibility of assigning selected databases for typologically determined customers. Application administrators have a comprehensive database access, due to the ability to modify permissions and customer requirements. It is essential that these are approved by the management of the application interfaces.

\section{What an infrastructure manager should know}

Manage infrastructure for executing state-owned infrastructure, boasting capacity for non-discriminatory employment and quality of employment under the auspices of the modernization and accounting department.

Železnice Slovenskej republiky (ŽSR) serve as railway infrastructure manager and as an administrator of railway lines in Slovak republic (Gašparík, et al., 2015). Its objective is to (Gašparík, et al., 2015):

- $\quad$ keep the railway line in working order;

- $\quad$ enable the use of railway infrastructure by other legal entities that demonstrate financial and professional competence, integrity, technical competence of rolling stock and ensure safe and smooth railway operation.

While in freight transport, carriers protect their knowhow and participation in transport, in passenger transport they are ahead in special offers, discounts and other offers for passengers.

It is necessary for the infrastructure manager to see every passenger and freight transport on the network at any time. The number of trains on the network on a given day is monitored by the infrastructure manager according to relation 1 .

$$
\text { Počet všetkých vlakov }=P T+F T+L T+S T
$$

where:

PT - passenger trains (express trains, fast trains a commuter trains)

FT - freight trains (freight express trains, continuous freight train, handling trains, and siding trains)

LT - locomotive trains

ST - service trains operated by infrastructure manager

A statistical overview for the last ten years is shown in Figure 2 in train-kilometres.

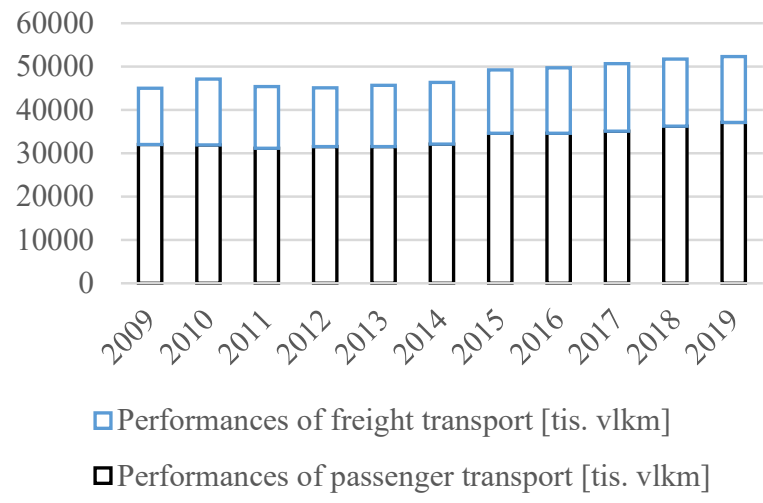

Fig. 2. Performance of passenger and freight transport on the ŽSR network in the years $2009-2019$ in thousand trainkilometres (Železnice Slovenskej republiky, 2009 - 2019)

Revenues from the railway fee also derive from the monitoring of passenger and freight train performance. It is clear from Graph 2 that performance in either passenger or freight transport was relatively stable with smaller fluctuations, mostly caused by external factors. Figure 3 shows the revenues resulting from the railway toll in the years 2011 - 2019, as in 2011 there was a change in the principle and structure of railway tolls.



Fig. 3. Revenues from the fee for railway infrastructure in the years $2011-2019$ in thousands $€$ (Železnice Slovenskej republiky, 2009 - 2019)

In addition to economic indicators, the infrastructure manager, e.g., it also monitors extraordinary events (accidents, incidents, etc.), the transport of extraordinary consignments, or the condition of railway station buildings and other ones assigned to it.

\section{What passenger $\&$ freight carriers should know}

Carriers in passenger and freight transport provide information to the infrastructure manager on the basis of the Electronic Data Exchange Agreement (hereinafter EVI). Based on this contract, the information systems of the carriers and the infrastructure manager are interconnected. Each carrier has different types of access rights, according to different criteria (Čamaj \& Gašparík, 2010).

Table 1 lists the selected monitored indicators of individual carriers 
Table 1. Selected monitoring indicators for passenger and freight carriers

\begin{tabular}{|c|c|}
\hline $\begin{array}{c}\text { Passenger } \\
\text { carriers }\end{array}$ & Freight carriers \\
\hline passenger numbers & $\begin{array}{c}\text { numbers of transported goods by } \\
\text { commodities }\end{array}$ \\
\hline \multicolumn{2}{|c|}{ economic indicators } \\
\hline \multicolumn{2}{|c|}{ train path order } \\
\hline important dates for the construction of the timetable \\
\hline exclusion & route diversions \\
\hline
\end{tabular}

For comparison, Figure 3 shows the number of licenses granted for passenger and freight transport and the number of real passenger and freight carriers to change the GVD in December 2020.

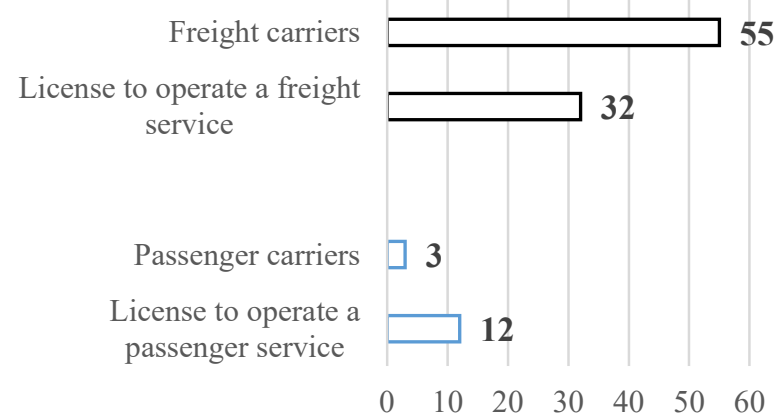

Fig. 3. Comparison of the number of licenses granted in passenger and freight transport with the number of active carriers (Dopravný Úrad Slovenskej republiky, 2019)

(Železnice Slovenskej republiky, 2020)

Of interest is the higher number of freight carriers than licensees for this activity. This is because a license obtained in any country is valid in the territory of all EU Member States (Kendra, et al., 2020).

It turns out that, despite the open market for passenger rail transport, the Slovak Republic is not so topical for passenger carriers. Among other things, this is due to the minimum number of competed lines on which other carriers can provide services in passenger transport, to which the state as the customer will reimburse economically justified costs.

\section{What passengers should know}

For passengers, the liberalization of the rail passenger market has several advantages and disadvantages. These are described in Table 2.

Tab. 2. Benefits \& disadvantages of a liberalized railway market

\begin{tabular}{|l|l|}
\multicolumn{1}{|c}{$\begin{array}{c}\text { The benefits of a } \\
\text { liberalized market }\end{array}$} & \multicolumn{1}{c|}{$\begin{array}{c}\text { Disadvantages of a liberalized } \\
\text { market }\end{array}$} \\
\hline lower cost of transport & non-uniform tariff \\
\hline higher transport comfort & $\begin{array}{l}\text { the problem of buying one ticket for } \\
\text { the whole route }\end{array}$ \\
\hline more connections & $\begin{array}{l}\text { problem with transfer and loss of } \\
\text { connection }\end{array}$ \\
\hline loyalty program & mutual derecognition of revenues \\
\hline
\end{tabular}

While in freight transport, carriers guard their knowhow and participation in transport, in passenger transport they are ahead in special offers, discounts and other offers for passengers.

Most infrastructure managers provide passengers with a tool to track the position of trains with information on delays or alternative bus services in the event of a closure. Figure 4 shows a map of ŽSR, on which passengers have access to such information in real time.

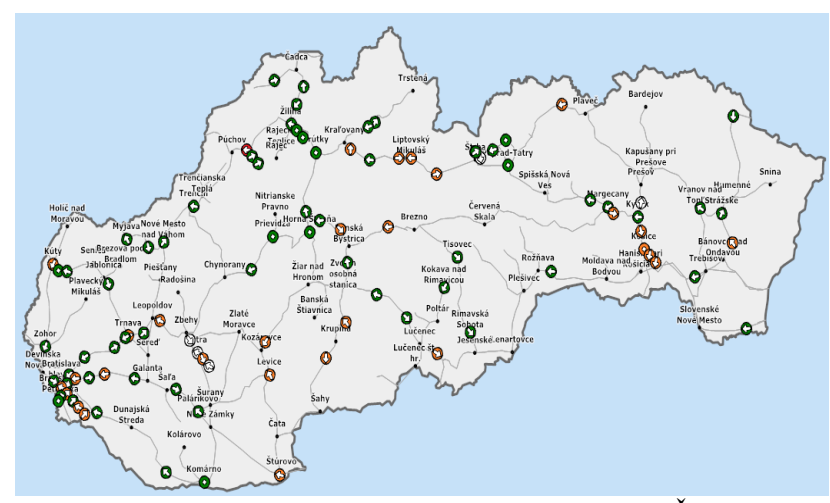

Fig. 4. Map with the position of passenger trains (Železnice Slovenskej republiky, 2020)

After clicking on the train by the user, the basic information about the train will be displayed as (Železnice Slovenskej republiky, 2020):

- category, number, train label,

- time and date of departure from the departure station with time and date of arrival at the destination station,

- the name of the last travelled point with the current delay in minutes,

- the name of the last waypoint crossed,

- time at the last crossed transport point,

- time according to the timetable at the last travelled point,

- carriers name.

The delay scale of the individual trains is color-coded as shown in Table 3.

Tab. 3. Colour scale of train delay times (Železnice Slovenskej

\begin{tabular}{|l|l|}
\multicolumn{1}{c}{ Colour } & \multicolumn{1}{c|}{ Delay } \\
\hline & $0-5$ min. \\
\hline & $6-30$ min. \\
\hline & 30 and more min. \\
\hline & replacement bus service \\
\hline
\end{tabular}

In this way, the passenger has an overview of the current departure / arrival time of his train. It is also worth mentioning the idea to expand this information to the Slovak radio airwaves, where it would be appropriate to create a so-called A "rail service" to inform potential passengers of current delays and current emergencies. 


\section{Conclusion}

Liberalization of the transport market brings with it both positives and negatives. Trying to unify the flow of information with an overlap to a satisfied customer is beneficia 1 . With the unification of the information flow, trade secrets need to be maintained in order to make rail companies competitive.

The article discusses the possible capabilities of the ERIC Mobile application, which is to be connected between the infrastructure manager, carriers, and passengers. Combining the proposed measures into one application would create an acceptable possibility for all components of the rail market to function. Not only would communication be facilitated, and competitiveness increased, but above all customer care would be intensified to a greater extent.

\section{Acknowledgment}

The paper was supported by the project EUREKA E!3156 - ERIC Mobile - "European Rail Information Centre in Freight Transport for End-users on Mobile Platforms" at Faculty of Operations and Economics of Transport and Communication, University of Žilina, Slovakia.



innovation across borders



MINISTERSTVO ŠKOLSTVA, VEDY, VYSSUMU A ŠPORTU

\section{References}

Busu, M., Busu, C., 2015. The Liberalization Process of the Railway Sector in Romania and Some Infringement Case Studies. Bucharest, Proceedings of the 9TH International Management Conference: Management and Innovation for Competitive Advantage.

Čamaj, J., Gašparík, J., 2010. In: Informačné a komunikačné technológie $v$ železničnej doprave. $1^{\text {st }}$ ed. Žilina: EDIS vydavatel'ské centrum Žilinskej univerzity.

Dopravný Úrad Slovenskej republiky, 2019. Zoznam platných licencií. [Online] Available at: http://drahy.nsat.sk/wpcontent/uploads/sites/3/2020/11/20201113_licencie_web.pd f [Cit. 25 November 2020].

Gašparík, J., Lichner, D., Blaho, P., 2015. Železničná dopravná prevádzka: In: Základy železničnej dopravnej prevádzky. 1st ed. Žilina: EDIS - vydavatešské centrum Žilinskej univerzity.

Kendra, M., Stoilova, S., Munier, N., Skrúcaný, T., 2020. Multicriteria evaluation of railway network performance in countries of the TEN-T orient-east med corridor. Sustainability, 12(4), p. 22.

Laperrouza, M., 2009. Does Liberalization of the European Railway Sector Increase Systematic Risk? In: Critical infrastructure Protection III, Hanover.

Železnice Slovenskej republiky, 2009 - 2019. Years book [Online] Available at: https://www.zsr.sk/o-nas/vyrocnespravy/ [Cit. 24 Movember 2020].

Železnice Slovenskej republiky, 2020. Map of ŽSR. [Online] Available at: http://mapa.zsr.sk/ [Cit. 25 November 2020].

Železnice Slovenskej republiky, 2020. Carriers sheet. [Online] Available at: https://www.zsr.sk/dopravcovia/infrastruktura/zoznamdopravcov/ [Cit. 25 November 2020]. 